\title{
CAN THE VIOLENT BEAR IT AWAY?
}

VOLUME 13, NO, 5

MAY. 1970

WoRLDVIEW is published monthly [except for a combined Juby-Aurust iesuel by the Council bo Religion and International Af tairs, Subscription $\$ 4, \infty$ for one year; $\$ 7, \infty$ for two years; $\$ 9.00$ for three years.

Address: 170 East 64th Street, New York, New York 10021 TE 84120

EDITORIAL BOARD

James Finn: Editor

John R. Inman

A. William Loos

Editorial Assistants:

Susan Woolfson

Kip Zegers

Contributing Editors: Doneid Brandon, Jerald C. Brauer, Ernest W. Lefever, Bernard Murchifand, Edmund Stillman

\section{CONTENTS}

in the Magazines

2

Cari the Violent Bea it Away?

Arthur. J. Moore

Deception and Policy

Danial C. Maguire

Editorials

Looking at Catonsville

Coming Home to \& New America Thomats Molnar

On trio Moral ińplications of Torture and Exemplany Astassination $\quad 12$

"The Perls of Rotoim Isolation" 16 Corrospofidence

Relating to Southier Africa:

A Voice from the Church other voices

$\therefore$

Rowdur are niminded that worldview woldomes

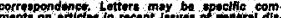

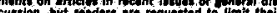
cuters to ono werds

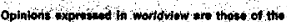
authiors and not mocenterlly of the councl on

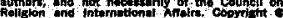

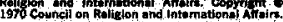

In the general state of tumoil in the United States today, one of the most commonly sorended notes of aceepted wisdom is the warning against the use of violence by such gronps as students, the Now Left and militant blacks. From the rhetorical overkill of the Vice l'resident through the avuneular viewing-with-alarm of the New York Fimes to the parlor psychoanalysis of such domesticated radicals as Itving Howe, the message is the same-violence is criminal madness.

One does not have to be an adnirer of violence to olserve a curious doulale standard in many of these admonitioms. Put in its simplest terms, this might be expressed ins the distinction between official, hence legitimate, violence, and unofficial, hence illegitimate, violence. Put more formally, this is atr attempt to substitute what Weloster's New International Dictionary gives as the secondary definition of the word- injury done to that which is entitled to respect, reverence, or olbservance; unjust force"-for its primary definition-"broadly, exertion of any physical force considered with reference to its effect on another tham the agent . .."

This bit of simple definition is neecssary becnuse of the efforts, by all sides in this dispute, to claim that there is good violence (theirs) and bad violence (that of the other side). Such a claim overlooks the most elementary fact about violence: it is nentral, Violence knows no moral cuds. It is avaitable to all men; it belongs to nonc.

It is part of the liypocrisy of all governments and status fuos that their violence is somedhow sanctified, that common consent makes superior virtue. This is the justification offered by such groveruments as Brazil, Greece, China, South Africa, Russia, Iraq, Israel, and many others, our own included. A comforting argument to the majority, it helps explain theit apathy about governmental violence and the lubbutb with which they greet the violent acts of individuals. Morally and logically, however. it is not much of an argument and serves mostly as al vestigial remain of the theors of the divine origin of the state.

But the divine origin of the state is not of much interest to those groups in our society who regard the contemporary state as owing its derivation much more to the devil, and it is not difficult for them to sete the fallacy of this position. In its place they put a reverse theory, one which might be labelled "right makes miglit." Ficed with a wicked and powefful adversary to whom moral irguments are meaningless, the use of violence is justified by superior insight and morality.

This argument is self-serving, but not necessarily any more so than those of the groups it sechs to overthrow. The groups un the out in our society nowhere show how much they are a 
part of our society than in the way they accept its implicit assumptions. Of these assumptions, none is more pervasive than the idea that victory is the final test. In American life, there are "winners" and there are "losers,". and that exhausts the categories. An idea "works" or "doesn't work." The ultimate sin in our society is to lose.

Therein lies the truth of Mr. Rap Brown's celebrated remark about cherry pie. Americaijs are rot by nature any more violence-prone than, say; the Swiss, but their cultural imperatives reward violence a great deal better. This is the lesson of the ghetto riots; it is the lesson of the "love children": turned into workers in bomb factories; it is, abore all, the lesson of Vietnam.

What then? Is violence simply the way of the world? The passage in Matthew (11;12) alluded to in the title of this editorial (and famitiar to readers of the late Flannery O'Connor) says, "From the days of fohn the Baptist until now the Kingdom of Heaven has suffered violence, and men of violence take it by force." The statement occurs in the context of a waming of Divine judgment on those who refuse to accept prophets when they appear.

How to distingrish the true prophet from the false one is one of the most vexing problems of history, no less so in a society which specializes in marketing prophets much as any other commodity. One might very well argne that the problen is even more difficult in a media society. It is reassuring to argue that revilision against the war in Vietnam is due largely to seeing the normal violence of war on television in our living rooms. But one wonders if the sequence in Follini's Satyricon, where a man's arm is actually chopped off as part of a theatrical performance, is not simply a reminder of ancient cruelty but also a piediction of things to enme.

Non-violence has always received sentimental lip service in this world, but little else. Gandhi and Martin Luther King, Jr. were not even allowed to die non-violently, solet us not be too glib about forswearing violence. Perhaps the time is coming when the sheer violence of our society will bring forth, in desperation, a new crop of advocates of non-violence as the atomic bomb produced a new hreed in the nuclear picifists.

Let us hope so. In the meantime, we nust struggle with the problems of how to produce a society based as littlc as possible on coercion; a socicty that truly does value multiplicity rather than conformity but yet does not disintegrate. Those problems arc complex and difficult, but there is one thing that is necessary before attempt ing any solution. We must stop lying to one another and, more important, to ourselves. There is no benign violence. The Chicago Police and the Weathermen, the F.B.I and the Black Panthers are morally in the same boat. We may judge one necessary and the other not, but that is a prudential judgment only. For violence is a psychotic whore; she will sleep with any of us in turn or all together, but in the end she will turn and kill us all.

Arthur J. Moore

\section{DECEPTION AND POLICY}

On the human affectivity scale, the love of truth holds no primacy. There are a lot of things we like more. Ease and clarity are examples. And when deceits promote ease and clarity, we fall in love with deception and resist the truth as we would a rival. None of us are all that alien to Elwood P. Dowd, the visible hero of II arivet who, when urged to le realistic, professed that he had tried reality and found it wanting.

Now let it be said that ease and clarity are no mean values. And yet, securing them in a world of mounting ambiguity and complexity often requires considerable sacrifice at the level of truth. A truly oljective view of today's social realities brings $i s$ into agonizing confrontation with $a b$ surdities, threats, and contradictions. The effort for oljectivity yields no ease and little clarity. The guest for truth is a rough and abrasive pilgrimage. Deception, imposed or self-administered, is the casy and obrious solution. Small wonder, then, that deception is in such strong dentand and copions stupply on our current national scene.

No vialyle government, of course, has'ever been :naware of the possibilities of deception. Deception, conccived outside of comtext, is a morally nentrat notion. In certain contests, it can be good. There ate tender deceptions that preserve relitionships from inevitable weakness and there are strategic deceptions that make diplomacy and politics feasible arts. Deception can serve and be good. It carr also dominate and he bad.

The Nixon Administration did not initiate po litical deception any more than Johnson invented incredibility: This Administration has, however, been emitting some distinctive and high-profile deceptions to an avidly receptive nation. But now some of the tangled wehs that have heen woven 